\title{
Wychodźstwo z województwa poleskiego za ocean. Zarys problematyki
}

Problemem badawczym niniejszego artykułu jest pokazanie procesów i głównych kierunków emigracyjnych z województwa poleskiego, będącego częścią polskich Kresów Wschodnich. Emigracja z województwa poleskiego jest rozpatrywana $\mathrm{w}$ kontekście uwarunkowań zewnętrznych i wewnętrznych, z uwzględnieniem polityki emigracyjnej międzywojennego państwa polskiego. Analiza dotyczy wychodźstwa za ocean - do krajów Ameryki Północnej i Południowej w okresie międzywojennym, a ściślej w latach 1921-1938. Zakres chronologiczny wynika $\mathrm{z}$ faktu, że województwo poleskie zostało utworzone w 1921 roku, a cezura końcowa dotyczy ostatniego roku, dla którego są dostępne dane dotyczące emigracji z międzywojennej Polski.

\section{Polityka państwowa w zakresie emigracji}

II Rzeczpospolita (II RP) była państwem charakteryzującym się wysoką stopą przyrostu naturalnego ludności i w związku z tym - państwem z wysokim potencjałem emigracyjnym. Nadwyżka ludności rolniczej i słabo rozwinięty przemysł w miastach, który nie był w stanie tej nadwyżki zaabsorbować, spowodowały, że Polska występowała jako źródło zasobów ludzkich dla innych krajów ${ }^{1}$.

Od początku istnienia II RP jej władze odbierały wychodźstwo jako naturalny proces, który może przynieść pozytywne efekty dla kraju: odciążyć przeludnioną wieś, zmniejszyć stopę bezrobocia oraz (jak wtedy myślano) - wzmocnić Polonię za granicą $\mathrm{i} w$ związku $\mathrm{z}$ tym pozycję Polski w świecie. $\mathrm{W}$ okresie rządów sanacji do tych względów dołączyły też kwestie uregulowania stosunków naro-

1 A. Kicinger, Polityka emigracyjna II Rzeczpospolitej, Warszawa 2005, s. 4, 6; H. Janowska, Emigracja zarobkowa z Polski 1918-1939, Warszawa 1981, s. 22-23, 37, 69, 89. 
dowościowych skierowane na wzmocnienie żywiołu polskiego², co było aktualne, zwłaszcza na Kresach Wschodnich, oraz zamiary przeprowadzenia akcji kolonizacyjnej za oceanem.

Polityka emigracyjna II RP zakładała wolność wychodźstwa. Jednocześnie wprowadzono nadzór i opiekę aparatu państwowego nad ruchami emigracyjnymi. Wszelka, niesankcjonowana przez władze agitacja i rekrutacja emigrantów została zabroniona ${ }^{3}$.

Od początku realizacja polityki państwowej w zakresie emigracji została powierzona Ministerstwu Spraw Zagranicznych (MSZ) oraz Ministerstwu Pracy i Opieki Społecznej (MPiOS). W latach dwudziestych funkcje głównego koordynatora pełniło MPiOS, a spośród kilku urzędów podlegających temu ministerstwu, najbardziej obszerne kompetencje w kwestiach emigracyjnych posiadał utworzony w 1920 roku Urząd Emigracyjny. Do jego funkcji należało przygotowanie tekstów aktów prawnych dotyczących spraw emigracyjnych, a także opracowanie danych statystycznych w zakresie wychodźstwa, zbieranie i udostępniane zainteresowanym instytucjom i urzędom informacji o sytuacji na zewnętrznych rynkach pracy, opiekowanie się emigrantami w trakcie przygotowania do wyjazdu i w czasie podróży ${ }^{4}$.

Podsumowaniem dotychczasowego doświadczenia w zakresie regulowania spraw emigracyjnych zostało przyjęte w 1927 roku Rozporządzenie Prezydenta Rzeczypospolitej o emigracji ${ }^{5}$.

W okresie Wielkiego Kryzysu wychodźstwo uległo znacznemu zmniejszeniu. Skorygowana została też polityka emigracyjna państwa oraz - w celu optymalizacji wydatków budżetowych - wprowadzono zmiany w administrowaniu emigracją. W 1930 roku Liga Morska i Rzeczna została przekształcona w Ligę Morską i Kolonialną, działalność której polegała m.in. na poszukiwaniu odpowiednich terenów i propagowaniu tam osadnictwa. Po 1932 roku MPiOS straciło wpływ na politykę emigracyjną, a zasadniczą rolę w tej sferze przejęło MSZ, które realizowało te funkcje do wybuchu II wojny światowej.

\footnotetext{
2 W. Śleszyński, Województwo poleskie, Kraków 2014, s. 275-289.

3 H. Janowska, Emigracja zarobkowa..., s. 103; eadem, Emigracja z Polski w latach 1918-1939, [w:] Emigracja z ziem polskich w czasach nowożytnych i najnowszych (XVIII-XX w.), (red.) A. Pilch, Warszawa 1984, s. 327-328; A. Gawryszewski, Ludność Polski w XX wieku, Warszawa 2005, s. 418.

4 Dekret o organizacji państwowych urzędów pośrednictwa pracy i opieki nad wychodźcami, Dz.U.R.P. Nr 11 (1919), poz. 127; Rozporządzenie Rady Ministrów w przedmiocie utworzenia Urzędu Emigracyjnego przy Ministerstwie Pracy i Opieki Społecznej, Dz.U.R.P. Nr 39 (1920), poz. 232; Rozporządzenie Rady Ministrów z dnia 9 czerwca 1921 r., Dz.U.R.P. Nr 64 (1921), poz. 403; H. Janowska, Emigracja z Polski..., s. 347.

5 Rozporządzenie Prezydenta RP z dnia 11 października 1927 r., Dz.U.R.P. Nr 89 (1927), poz. 799; H. Janowska, Emigracja z Polski..., s. 348-349; A. Gawryszewski, op. cit., s. 418-419 .
} 
Natomiast rolę głównego organizatora wyjazdów i opiekuna emigrantów zaczęła odgrywać utworzona jeszcze w 1930 w Warszawie spółka Syndykat Emigracyjny S.A. ${ }^{6}$

\section{Charakterystyka województwa poleskiego i jego mieszkańców}

Województwo poleskie pojawiło się w strukturze administracyjnej II Rzeczypospolitej 19 lutego 1921 roku. Pokój ryski zawarty w marcu 1921 roku po wojnie polsko-bolszewickiej ustalił przebieg granicy wschodniej odrodzonego państwa, dzieląc rozległy historyczny i geograficzny region Polesia między Polską a socjalistycznymi republikami radzieckimi, które wkrótce weszły w skład Związku Socjalistycznych Republik Radzieckich. Należąca do Polski część Polesia administracyjnie stanowiła część województw poleskiego i wołyńskiego. Dalej w ramach niniejszego artykułu określenie Polesie będziemy wykorzystywać wyłącznie w stosunku do województwa poleskiego.

Powierzchnia tego województwa na początku lat dwudziestych XX wieku wynosiła 42,3 tys. $\mathrm{km}^{2}$. Pod względem administracyjnym składało się ono z 9 powiatów, na terenie których znajdowało się 28 gmin miejskich i 118 gmin wiejskich ${ }^{7}$.

Województwo poleskie leżało na polodowcowej równinie, środkiem której płynie rzeka Prypeć z mnóstwem dopływów. Większość terenu była zajęta porośniętymi lasem błotami i piaskiem. Niska jakość gleby oraz wysoka wilgotność powietrza wpływały ujemnie na uprawy. Pod względem użytkowania gruntów województwo miało najwyższy odsetek nieużytków oraz najniższy odsetek gruntów ornych w kraju, przy czym odsetek ziemi ornej obsianej też był bardzo niski (ok. 80\%). Niewystaczająca płodność ziemi i niekorzystne dla zdrowia warunki klimatyczne przyczyniły się do najniższych w kraju wskaźników zaludnienia terenu. Województwo poleskie charakteryzowało się najniższym w kraju wskaźnikiem osób zamieszkałych na wsi na 100 ha ziemi użytkowej8.

Jednocześnie cechą wyróżniającą województwo poleskie, jak również całe Kresy Wschodnie, była wielokulturowość oraz zróżnicowana struktura etniczna. Mieszkający tu ludzie posługiwali się różnymi językami, wyznawali różne wiary

6 Rozporządzenie Prezydenta RP z dnia 21 czerwca 1932 r., Dz.U.R.P. Nr 52 (1932), poz. 492; H. Janowska, Emigracja zarobkowa..., s. 112-113; eadem, Emigracja z Polski..., s. 349-351; E. Kołodziej, op. cit., s. 179-183; A. Gawryszewski, op. cit., s. 419.

7 Rocznik statystyki Rzeczypospolitej Polskiej 1923, s. 9.

8 Stownik geograficzny Królestwa Polskiego i innych krajów słowiańskich, t. VIII, Warszawa 1887, s. 580-581, 585-586; Atlas statystyczny, Warszawa 1930, tab. 13. 
i byli nosicielami różnych kultur 9 . Według danych pierwszego spisu powszechnego, przeprowadzonego w Polsce w 1921 roku, Polesie zamieszkiwało 880,9 tys. osób, w tym 427,4 tys. mężczyzn i 453,5 tys. kobiet, co wskazuje na zrównoważoną strukturę demograficzną. Powiatami z największą liczbą ludności, ponad 100 tys. mieszkańców, były: brzeski i piński (na terenie których znajdowały się najważniejsze ośrodki miejskie regionu), oraz łuniniecki i sarneński (które były największe pod względem terytorium) ${ }^{10}$.

Większość mieszkańców województwa była wyznawcami prawosławia (697,4 tys. osób). Do innych znaczących liczebnie grup religijnych należały osoby wyznania mojżeszowego (110,6 tys. osób) oraz katolicy obrządku łacińskiego (68,7 tys. osób).

Bardziej zróżnicowany i złożony obraz wyłania się natomiast po analizie danych dotyczących uwzględnionych w spisie narodowości. Pod względem etnicznym najliczniejsi na terenie województwa poleskiego byli Białorusini - 375,2 tys. osób. Najwiecej osób z wykształconą białoruską świadomością narodową mieszkało w powiecie brzeskim oraz w powiatach wschodnich województwa: pińskim, łuninieckim i stolińskim. Liczba mieszkańców województwa, którzy wskazali narodowość polską wynosiła 214,1 tys. osób. Stosunkowo więcej Polaków zamieszkiwało centralne powiaty kobryński i prużański oraz główne miasta regionu Brześć i Pińsk. Według spisu, odsetek ludności polskiej na Polesiu był najniższy w kraju i stanowił niespełna jedną czwartą mieszkańców (24,3\%). Faktycznie, był chyba jeszcze kilkakrotnie mniejszy, jeśli uwzględnimy fakt, że wśród osób, które wskazały narodowość polską ponad dwie trzecie stanowiły wyznawcy prawosławia i judaizmu. Z kolei znaczna liczba osób wskazała narodowość rusińską (ukraińską) - 156,1 tys. osób. Ukraińcy zamieszkiwali głównie południowe powiaty sarneński i koszyrski. Ludność żydowska (91,3 tys. osób) była skoncentrowana w miastach i miasteczkach, w których często stanowiła większość mieszkańców ${ }^{11}$.

Specyficzną grupą etniczną byli Poleszucy, których liczba na terenie województwa wynosiła 38,6 tys. ${ }^{12}$.

9 E. Kirwiel, Kresy Pólnocno-Wschodnie Rzeczypospolitej Polskiej w latach 1918-1939. Oblicze polityczne, Lublin 2011, s. 28.

10 Skorowidz miejscowości Rzeczypospolitej Polskiej, t. VIII, Warszawa 1924, s. 1-2.

11 Ibidem; Rocznik statystyki... (1923), s. 14; П. Терешкович, Этническая история Беларуси ХІХ - начала XX в. в контексте Центрально-восточной Европы, Минск 2004, s. 85-90.

12 Rocznik statystyki... 1923, s. 14; Poleszucy bądź tutejsi - posiadająca poczucie własnej odrębności lecz w okresie międzywojennym nieposiadająca wykszłtowanej świadomości narodowej ludność wiejska na pograniczu regionów zamieszkałych przez Białorusinów i Ukraińców. Posługują się wschodnio-słowiańskimi dialektami przejściowymi od języka ukraińskiego do białoruskiego, czasem uznawanymi za odrębny język poleski. 
Wskaźnik zaludnienia województwa poleskiego był najniższy w Polsce (20,8 mieszkańców na $1 \mathrm{~km}^{2}$ ), a w niektórych powiatach był jeszcze mniejszy, np. w łuninieckim - 16,6 osób/km², stolińskim - 16,2 osób/km², kossowskim - 13,6osób/km²13.

Miejscową ludność charakteryzował niski poziom życia ekonomicznego, słaba aktywność gospodarcza oraz wysoki stopień analfabetyzmu. W pierwszych latach po I wojnie światowej $85 \%$ ludności Polesia nie umiało ani czytać, ani pisać. Chociaż pod koniec lat dwudziestych XX wieku sytuacja nieco się poprawiła, analfabetami wciąż było $65 \%$ mieszkańców Polesia. Co czwarte dziecko w wieku szkolnym nie uczęszczało do szkoły. Podobnie sytuacja wyglądała w mieście wojewódzkim, Brześciu. W regionach zamieszkałych w większości przez prawosławnych stopień analfabetyzacji był najwyższy ${ }^{14}$.

Granice województwa poleskiego i wchodzących w jego skład powiatów kilkakrotnie się zmieniały. Do najważniejszych zmian należały: utworzenie w 1923 roku nowego powiatu stolińskiego z części gmin powiatów łuninieckiego, sarneńskiego i pińskiego; w 1926 roku wymiana gmin pogranicznych z województwami nowogródzkim i białostockim; wyłączenie w 1930 roku powiatu sarneńskiego z województwa poleskiego z przyłączeniem go do województwa wołyńskiego ${ }^{15}$.

Po tych zmianach, w 1931 roku powierzchnia województwa poleskiego wynosiła 36,7 tys. $\mathrm{km}^{2}$, a na jego terenie znajdowało się 14 gmin miejskich i 79 wiejskich. Liczba ludności wzrosła do 1131,9 tys. osób, w tym 549,6 tys. mężczyzn i 582,3 tys. kobiet. Gęstość zaludnienia wzrosła do 30,9 osób $/ \mathrm{km}^{2}$. Warto zwrócić uwagę, iż porównywalne pod względem powierzchni sąsiednie województwo wołyńskie liczyło wtedy znacznie, prawie dwa razy więcej, mieszkańców (2085,6 tys. osób) ${ }^{16}$.

Podczas przeprowadzonego w 1931 roku drugiego spisu powszechnego zmieniono zestaw pytań: zamiast wyzniania i narodowości, osoby ankietowane podawały wyznanie i język ojczysty. Według tych danych, ponad trzy czwarte mieszkańców Polesia poslugiwało się jednym z języków wschodniosłowiańskich (tutejszy, białoruski, ukraiński, rosyjski), 14,5\% - polskim, 10,0\% - jidysz lub

\footnotetext{
13 Rocznik statystyki... (1923), s. 12.

14 E. Kirwiel, op. cit., s. 28; P. Cichoracki, Polesie nieidyliczne. Zaburzenia porzqdku publicznego $w$ województwie poleskim $w$ latach trzydziestych XX w., Lomianki 2007, s. 14.

15 Rozporządzenie Rady Ministrów z dnia 6 grudnia 1922 r., Dz.U.R.P. Nr 116 (1922), poz. 1051; Rozporządzenie Rady Ministrów z dnia 4 maja 1926 r., Dz.U.R.P. Nr 45 (1926), poz. 277; Rozporządzenie Rady Ministrów z dnia 14 lipca 1926 r., Dz.U.R.P. Nr 72 (1926), poz. 415; Rozporządzenie Prezydenta Rzeczypospolitej z dnia 29 listopada 1930 r., Dz.U.R.P. Nr 82 (1930), poz. 649.

16 Drugi powszechny spis ludności z dnia 9 grudnia 1931 r. Mieszkania i gospodarstwa domowe. Ludność. Stosunki zawodowe. Województwo poleskie, Warszawa 1938, s. 2.
} 
hebrajskim. Większość ludności (62,5\%) podała język tutejszy jako ojczysty, natomiast deklarowanie języka białoruskiego lub ukraińskiego było wyrazem wykształtowanej odpowiedniej świadomości narodowej. Odsetek ludności polskojęzycznej, rosyjskojęzycznej, a także żydowskiej był najwyższy w powiatach z większymi ośrodkami miejskimi (Brześć i Pińsk) ${ }^{17}$.

Warto zwrócić uwagę na strukturę zawodową mieszkańców województwa. Zdecydowana większość zajmowała się rolnictwem (80,6\%). W przemyśle zatrudnienie znalazło tylko 7,9\% mieszkańców, a najbardziej rozwiniętymi przemysłowo powiatami były brzeski, piński i łuniniecki. W handlu pracowało ok. 3,4\% mieszkańców województwa, a odsetek innych zawodów był praktycznie znikomy ${ }^{18}$.

\section{Procesy migracyjne w województwie poleskim}

W odbudowanym po latach rozbiorów państwie polskim i jego częściach występowały różnorodne procesy migracyjne: zewnętrzne (emigracja, reemigracja, repatriacja) oraz wewnętrzne. Polesie, należące przed I wojną światową do zaboru rosyjskiego, w latach 1915-18 częściowo znajdowało się w niemieckiej strefie okupacyjnej. Przed frontem, na polecenie władz rosyjskich, miejscowa ludność masowo ewakuowała się w głąb Rosji. Po odbudowie państwa polskiego i ostatecznym zakończeniu działań wojennych, województwo poleskie przyjęło największą w Polsce liczbę repatriantów (przeważnie wyznania prawosławnego) ze wschodu. Od czerwca 1921 do końca 1922 roku przybyło tu 157,2 tys. osób (23,0\% wszystkich repatriantów do Polski), które osiedliły się głównie na terenie zachodnich i centralnych powiatów ${ }^{19}$.

W latach dwudziestych XX wieku wszystkie powiaty województwa poleskiego wyróżniały się napływem migrantów wewnętrznych, głównie z Polski centralnej. Liczba tych migrantów nie została dokładnie ustalona, choć można przyjąć, że było to ok. 40 tys. osób ${ }^{20}$.

Emigracja z Polesia za ocean była wychodźstwem stałym, o charakterze osadniczym. W odróżnieniu od innych województw, nie było tam emigracji sezonowej. Przyczyną tego zjawiska mógł być brak perspektyw życiowych w rodzinnych stronach. Trzeba zwrócić uwagę, że mimo biedy panującej zwłaszcza we wschodnich powiatach województwa, możliwość emigrowania posiadały osoby

17 Ibidem, s. 25-27; H. Majecki, Problem samookreślenia narodowego Poleszuków w Polsce okresu międzywojennego, [w:] Загароддзе-3, Мінск 2001, s. 152-153.

18 Maty rocznik statystyczny 1938, s. 30, 33, 37.

19 Rocznik statystyki... (1923), s. 29; J. Tomaszewski, Z dziejów Polesia 1921-1939, Warszawa 1965, s. 20-23; Polesie w polityce rządów II Rzeczypospolitej, Białystok-Kraków 2009, s. 7.

20 Atlas..., tab. 13; J. Tomaszewski, op. cit., s. 22-23, 35. 
dysponujące odpowiednimi środkami (np. po sprzedaży majątku), co było ściśle kontrolowane przez polskie władze emigracyjne ${ }^{21}$.

\section{Działalnosć lokalnych urzędów odpowiadających za sprawy emigracyjne (na przykładzie Syndykatu Emigracyjnego)}

Działalność lokalnych urzędów odpowiadających za sprawy emigracyjne na terenie województwa poleskiego obrazują przechowywane w Państwowym Archiwum Obwodowym w Brześciu dokumenty agentur i oddziałów Syndykatu Emigracyjnego. Struktura Syndykatu zawierała oddziały okręgowe, podporządkowane im oddziały i na najniższym poziomie agentury - zlokalizowane $\mathrm{z}$ reguły w miasteczkach biura prowincjonalne, odpowiadające za jeden lub kilka powiatów. Na początku Syndykat posiadał 13 oddziałów, których liczba pod koniec lat trzydziestych XX wieku zwiększyła się do $27^{22}$.

W latach 1930-1931 tereny województw poleskiego i wołyńskiego obejmował swoim działniem okręgowy oddział Brześć. Na obszarze Polesia były mu bezpośrednio podporządkowane agentury w Kobryniu (dla powiatu kobryńskiego), Drohiczynie (dla powiatu drohiczyńskiego) i Prużanie (dla powiatów prużańskiego i kossowskiego), oraz oddział Pińsk, posiadający agenturę w Lunińcu (dla powiatów łuninieckiego i stolińskiego). Od 1932 roku w miejscu agentur działali przedstawiciele Syndykatu Emigracyjnego - korespondenci (gminni i powiatowi) spośród pracowników lokalnego samorządu. Po zmianach w strukturze, oddział okręgowy Brześć posiadał oddziały korespondencyjne w powiatach brzeskim, drohiczyńskim, kobryńskim, kosowskim, prużańskim województwa poleskiego, powiecie bialskim województwa lubelskiego; podporządkowany mu oddział Pińsk - w powiatach pińskim, łuninieckim, stolińskim województwa poleskiego ${ }^{23}$.

Funkcjonowanie biur Syndykatu Emigracyjnego na terenie województwa poleskiego spotkało się na początku z niechęcią urzędników i obojętnością społeczeństwa oraz ze zdecydowaną walką ze strony nielegalnych pośredników emigracyjnych (w roli których często występowali przedstawiciele ludności żydow-

21 Mały rocznik statystyczny 1939, s. 54; E. Kołodziej, Wychodźstwo zarobkowe z Polski 1918-1939, Warszawa 1982, s. 254.

22 H. Janowska, Emigracja z Polski..., s. 353-355; M. Radomska, op. cit., s. 14 (liczbę oddziałów podano dla całego kraju).

23 Государственный архив Брестской области. Путеводитель по фондам 1919-1939, Брест 2010, s. 50-52; Państwowe Archiwum Obwodu Brzeskiego (dalej - PAOB), z. 2082, op. 1, t. 78, k. 1-3 - odpis miesięcznego sprawozdania rozumowego kierownika agentury Syndykatu Emigracyjnego w Pińsku do centrali w Warszawie z dnia 16 grudnia 1930 roku. 
skiej). W rozwiązywaniu powstałych problemów przedstawiciele Syndykatu Emigracyjnego byli zwykle wspierani przez wojewódę poleskiego ${ }^{24}$.

W pierwszej połowie lat trzydziestych działalność Syndykatu Emigracyjnego S.A. została krytycznie oceniona przez MSZ jako nierentowna i nieskuteczna. Wskazano na niską aktywność emigracyjną ludności i niezbyt wysoki poziom przygotowania pracowników lokalnych placówek Syndykatu. Podjęte działania nie zwalczyły nielegalnego pośrednictwa w emigracji, które nadal kwitło, mimo stosowanych surowych kar (pozbawienie wolności, wysokie grzywny pieniężne $)^{25}$.

Nielegalnym pośrednictwem emigracyjnym, agitacją wychodźczą i oszustwami zajmowali się w latach 1931-1932 m.in. byli i aktualni pracownicy ekspozytury Urzędu Emigracyjnego w Brześciu ${ }^{26}$.

W związku ze znacznym ograniczeniem ruchu emigracyjnego zamorskiego w okresie kryzysu, rozwinęłą się działalność różnych francuskich biur rolniczych, które za pomocą ogłoszeń w gazetach, specjalnych ulotek i agentów, starały się zwerbować osadników z Polski, również z województw wschodnich, zachęcając ich korzystnymi warunkami nabycia ziemi i osiedlenia się we Francji. Interes biur polegał na pośrednictwie w zawieraniu umów. Emigranci często pozbywali się majątku w Polsce po niskich cenach; niezorientowani w realnych warunkach nabycia ziemi i specyfice jej uprawy we Francji, po pewnym czasie wracali zrujnowani do ojczystego kraju lub, nie mając już pieniędzy na powrót, zasilali szeregi francuskich bezrobotnych ${ }^{27}$.

W 1934 roku na Polesiu dwaj osobnicy, podający się za pułkowników kozackich byłej armii rosyjskiej z ramienia organizacji kozackiej pod nazwą $S K A P A$, nie mając zezwolenia i bez żadnego porozumienia się z władzami miejscowymi, dokonywali wśród chłopów-obywateli polskich rejestracji chętnych na wyjazd do Afryki. Pobierali od nich pieniądze, jako składki członkowskie oraz na prowadzenie korespondencji i starań u przedstawicielstwa organizacji we Francji ${ }^{28}$.

Przedsiębiorstwa okrętowe, które utraciły polskie koncesje żeglugowe zajmowały się czasami nielegalnym przewozem emigrantów z Polski do USA. Wykorzystywały one przypadki uzyskiwania przez emigrantów paszportów tzw. turystycznych oraz ulgowych, rzekomo dla celów rodzinnych lub majątkowych

24 Ibidem.

25 M. Radomska, op. cit., s. 14; PAOB z. 2082, op. 1, t. 5, k. 225, 227 - pismo Ministerstwa Opieki Społecznej z dnia 5 października 1936 roku w sprawie działalności Syndykatu Emigracyjnego.

26 PAOB, z. 377, op. 1, t. 6, k. 1, 6 - listy ekspozytury Urzędu Emigracyjnego w Brześciu.

27 Ibidem, k. 78-78v. - list kierownika ekspozytury Urzędu Emigracyjnego w Brześciu do starosty emigracyjnego w Dubnie w sprawie Biura Rolniczego Emila Schmidta (Agence Generale Agricole).

28 PAOB, z. 2082, op. 1, t. 3, k. 74-75 - pismo oddziału Syndykatu Emgracyjnego w Pisku do centrali w Warszawie z dnia 28 listopada 1934 roku w sprawie werbowania na wyjazd do Afryki. 
i w związku z tym, że posiadacze tych paszportów nie podlegają kontroli władz emigracyjnych, swobodnie przyjmowały takich pasażerów do USA ${ }^{29}$.

W ramach polityki emigracyjnej II RP zakładającej wspieranie ruchów wychodźczych, w latach trzydziestych XX wieku władze sanacyjne próbowały położyć szczególny nacisk na wzmożenie wychodźstwa mniejszości narodowych, zwłaszcza Żydów i Ukraińców. Propagatorami takiego podejścia były Liga Morska i Kolonialna, MSW i MSZ. Intensyfikacja wychodźstwa Białorusinów i Ukraińców z terenów wschodnich Polski do Brazylii, Argentyny i innych państw Ameryki Południowej była przewidywana w perspektywicznym planie emigracyjnym MSZ. Na zwolnionych terenach planowano osiedlić etnicznych Polaków. W 1936 roku utworzono polską linię okrętową do Ameryki Południowej, co też miało sprzyjać emigrowaniu rolników ukraińskich ${ }^{30}$. Halina Janowska stwierdza, że władze polskie w swoich dążeniach do zwiększenia wychodźstwa mniejszości narodowych, głównie Żydów i Ukraińcow, nigdy nie stosowały przymusu w stosunku do jakiejkolwiek grupy etnicznej ${ }^{31}$.

Na początku lat trzydziestych XX wieku, w polskiej polityce emigracyjnej pojawiły się też idee kolonizacyjno-osadnicze. Wśród potencjalnych terenów do kolonizacji rozpatrywano pewne rejony w Ameryce Południowej. Jednak mimo przykładanych staran, w praktyce strona polska raczej dostosowywała się do warunków stawianych przez kraje imigracyjne ${ }^{32}$.

\section{Kierunki i struktura emigracji za ocean}

Stany Zjednoczone były głównym kierunkiem emigracji z ziem polskich przed I wojną światową. Podstawowe przyczyny emigracji do Ameryki leżały w płaszczyźnie ekonomicznej. Wyjeżdżano z regionów zacofanych gospodarczo, o niskim stopniu urbanizacji i rozwoju przemysłu, z brakiem miejsc pracy oraz złożoną sytuacją agrarną. W Stanach Zjednoczonych w okresie przyśpieszonej industrializacji było łatwiej niż w kraju ojczystym, znaleźć pracę.

W porównaniu z Królestwem Polskim, emigracja zamorska z ziem byłego Wielkiego Księstwa Litewskiego była znacznie mniejsza, ponieważ mieszkańcy tych ziem mogli swobodnie się osiedlać na terenie całej Rosji. Mimo to ludność z terenów przyległych do wschodnich granic Królestwa dość masowo udawała się do USA. Emigracja ta była w znacznym stopniu emigracją żydowską. Ziemie

${ }^{29}$ PAOB, z. 377 , op. 1 , t. 6 , k. 73-73v. - poufny list wojewody poleskiego z dnia 18 grudnia 1931 roku do starostów powiatowych.

30 A. Zarychta, Emigracja polska 1918-1933 i jej znaczenie dla państwa, Warszawa 1933, s. 52-53; H. Janowska, Emigracja zarobkowa..., s. 143; E. Kołodziej, op. cit., s. 203-204, 206.

31 H. Janowska, Emigracja zarobkowa..., s. 143; eadem, Emigracja z Polski..., s. 363;

32 Eadem, Emigracja zarobkowa..., s. 136-137. 
zaboru rosyjskiego były jednym z głównych źródeł wychodźstwa żydowskiego do USA na początku XX wieku ${ }^{33}$.

Po przerwie, związanej z działaniami wojennymi w Europie, masowe wychodźstwo z ziem polskich do USA zostało wznowione i w latach 1919-1920 utrzymywało się na dość wysokim poziomie. Wybór kierunku emigracji był całkowicie świadomy: emigrowano do Stanów Zjednoczonych jako kraju, gdzie już byli krewni lub przynajmniej osoby pochodzące $\mathrm{z}$ tej samej miejscowości lub gminy ${ }^{34}$.

Dostęne dane statystyczne pozwalają stwierdzić, że w okresie międzywojennym z województwa poleskiego do Stanów Zjednoczonych wyemigrowało ok. 8,9 tys. osób ${ }^{35}$.

W maju 1921 roku w USA wprowadzono ustawę Emergency Quota Act, ograniczającą roczną liczbę imigrantów do 3\% liczebności danej grupy narodowej mieszkańców Stanów Zjednoczonych, według danych spisu z 1910 roku. W związku z tym nie wszystkim osobom, które otrzymały polskie wizy wyjazdowe, udało się uzyskać wizy amerykańskie. Konsulat USA w Warszawie, według obliczeń Urzędu Emigracyjnego, wydał w 1921 roku ok. 70 tys. wiz. Spowodowało to, że w drugim półroczu 1921 roku liczba wniosków wizowych na wyjazd do Stanów Zjednoczonych znacznie spadła. Dane odnośnie do wyjazdów z poszczególnych województw nie są dostępne. Biorąc pod uwagę obliczenia, w latach dwudziestych emigracja $\mathrm{z}$ Polesia wynosiła nie mniej niż 4\% emigracji z Polski do USA, możemy przyjąć że z województwa poleskiego w 1921 roku do USA faktycznie wyjechało ok. 2,8 tys. emigrantów ${ }^{36}$.

W 1922 roku biuro paszportowe Urzędu Emigracyjnego wydało mieszkańcom województwa poleskiego 1500 wiz na wyjazd do Stanów Zjednoczonych. Tak samo jak w poprzednim roku, nie wszyscy zarejestrowani emigranci mogli faktycznie wyjechać ze względu na ograniczenia imigracyjne wprowadzone ustawowo w USA. Jak wynika z danych, co trzecia osoba wyjeżdżająca w 1922 roku do USA była tam już wcześniej. Osoby te przeważnie posiadały tzw. Permit to Reenter - zezwolenie na powrót do Stanów Zjednoczonych w określonym terminie ${ }^{37}$.

${ }^{33}$ F. Stasik, Polska emigracja zarobkowa w Stanach Zjednoczonych Ameryki 1865-1914, Warszawa 1985, s. 19-20, 37, 48.

34 Ibidem, s. 42.

35 Mały rocznik... (1939), s. 52-55; Statystyka... (1933), s. 39-45; ibidem (1934), s. 38; ibidem (1935), s. 62; ibidem (1936), s. 53; ibidem (1937), s. 68; ibidem (1938), s. 25; ibidem (1939), Warszawa 1939, s. 38.

36 Rocznik statystyki... 1920-22, s. 335; A. Gawryszewski, op. cit., s. 422; A. Brożek, Polityka imigracyjna w państwach docelowych emigracji polskiej (1850-1939), [w:] Emigracja z ziem polskich..., s. 132; H. Janowska, Emigracja z Polski..., s. 327-328.

37 PAOB, z. 2082, op. 1, t. 3, k. 10 - list Centrali Amerykańskich Linii Okrętowych w Warszawie do lokalnych agentur, bez daty; Rocznik statystyki... (1923), s. 26-27. 
Ponad połowa emigrantów była niewykwalifikowana; a tylko $29 \%$ osób wyjeżdżało na własny koszt ${ }^{38}$. Wymienione fakty, a także znikome odsetki osób, które zostawiły w kraju majątek oraz jednoznacznie wskazały zamiar powrotu, pozwalają stwierdzić, że emigracja z województwa poleskiego do USA w 1922 roku miała charakter osadniczy.

W latach 1921-1922 emigracja do USA była przede wszystkim wychodźstwem osób wyznania mojżeszowego, które wyjeżdżały całymi rodzinami ${ }^{39}$. W przypadku mniej licznej emigracji chrześcijan występowały natomiast duże dysproporcje w strukturze płci, gdyż liczba wyjeżdżających kobiet była sześciokrotnie wyższa od liczby mężczyzn, co możemy wytłumaczyć masowym wyjazdem żon do przebywających w USA mężów.

Mimo ograniczeń imigracyjnych, USA wciąż pozostawały głównym kierunkiem wychodźtwa z Polski za ocean. Jednocześnie ponad połowa emigrantów zamorskich podała jako cel podróży nieokreślony kraj Ameryki Północnej i Południowej lub kraj niewiadomy. W związku z amerykańskimi ograniczeniami imigracyjnymi w kolejnych latach nastąpiło przekierowanie ruchu migracyjnego do innych, bardziej otwartych krajów zaoceanicznych, choć nie były to kraje docelowe. Są świadectwa o licznych, a czasem też skutecznych próbach nielegalnego przedostania się do USA przez Meksyk lub Kubę ${ }^{40}$.

Dla lat 1923-1924 brakuje danych statystycznych odnośnie emigracji z poszczególnych województw. Obliczenia na podstawie dostępnych danych krajowych wskazują na liczbę ok. 670 emigrantów do USA z województwa poleskiego w tych latach, a w kolejnych ich liczba się zmniejszyła. Był to bezpośredni efekt wprowadzenia jeszcze bardziej rygorystycznych ograniczeń imigracyjnych opartych na Immigration Act of 1924: do 2\% liczebności danej grupy etnicznej mieszkańców według danych spisu z 1890 roku Stany Zjednoczone przestały być głównym krajem docelowym emigracji. Wymieniona sytuacja utrzymała się do końca lat międzywojennych, na co miał potem wpływ także światowy kryzys gospodarczy $^{41}$.

W 1925 roku z województwa poleskiego do Stanów Zjednoczonych wyemigrowały 397 osoby. Spadek zainteresowania tym kierunkiem wychodźstwa wynikał ogólnie z ograniczeń w USA, ale na Polesiu był większy niż przeciętnie w kraju, głównie wskutek efektywnych działań organizacji syjonistycznych, co spowodowało tam masową migrację miejscowych Żydów do Palestyny ${ }^{42}$.

\footnotetext{
38 Rocznik statystyki... (1923), s. 25-27.

39 Rocznik statystyki... (1920-22), s. 337; Rocznik statystyki... (1923), s. s. 25-27.

40 A. Kicinger, op. cit., s. 11.

41 Rocznik statystyki... (1925-26), s. 99; A. Gawryszewski, op. cit., s. 422; A. Brożek, op. cit., s. 133.

42 Rocznik statystyki... 1925-26, s. 99-100; А.В. Мощук, Политическая деятельность Бунда на территории Западной Беларуси в 1921-1939 г2., „Веснік Брэсцкага універсітэта”, 2007, nr 2, s. 42-51.
} 
W kolejnych latach wychodźstwo z Polesia do USA nieco wzrastało, osiągając w 1929 roku liczbę 817 osób ${ }^{43}$.

Wielki Kryzys Gospodarczy, który rozpoczął się w 1929 roku, położył kres masowemu wychodźstwu. W drugiej połowie 1931 roku w województwie poleskim wydano już tylko 36 paszportów na wyjazd do USA, w tym 25 - osobom narodowości żydowskiej ${ }^{44}$.

W latach 1932-1937 - jak wynika z danych statystycznych - emigracja z Polesia do Stanów Zjednoczonych wahała się w granicach 55-95 osób rocznie. W 1938 roku - ostanim roku, dla którego są dostępne dane statystyczne wychodźstwo z Polesia do USA nieco wzrosło, do 158 osób $^{45}$.

Warto dodać, że także Kanada była obiektem zainteresowania wychodźców. Masowa emigracja z ziem polskich do Kanady rozpoczęła się również przed I wojną światową. Polityka zagospodarowania prerii otwierała możliwości nabywania ziemi, a budowa w tym kraju transkontynentalnej linii kolejowej wykreowała nowe miejsca pracy i potrzebę dodatkowej siły roboczej. Wśród wychodźców dominowały osoby ze wsi, często nieposiadające zawodu, narodowości głównie polskiej i ukraińskiej ${ }^{46}$.

Na podstawie dostępnych danych statystycznych oraz obliczeń własnych (dla lat 1921, 1923-1924) możemy stwierdzić, że w okresie międzywojennym z województwa poleskiego do Kanady wyjechało ok. 8 tys. osób. Emigracja do Kanady miała charakter zarobkowy. Często przyczyną wyjazdu do tego kraju była chęć przedostania się potem do USA ${ }^{47}$.

W pierwszej połowie lat dwudziestych XX wieku z Polesia do Kanady rocznie emigrowało od stu do kilkuset osób. Ponad dwie trzecie wychodźców do tego kraju stanowiły osoby wyznania mojżeszowego ${ }^{48}$.

W 1925 roku w Kanadzie, w związku z poprawą koniunktury gospodarczej i zagospodarowaniem terenów zachodnich, wzrosło zapotrzebowanie na siłę roboczą. W listopadzie tegoż roku władze kanadyjskie podpisały umowę z towarzystwami kolejowymi Canadian National Railways (CNR) oraz Canadian Pacific Railways (CPR), pozwalającą im sprowadzić do Kanady robotników rolnych z rodzinami oraz służbę domową. Rozpoczęła się masowa rekrutacja emigrantów z krajów Europy Środkowo-Wschodniej, głównie z Polski, ponieważ rząd

43 Statystyka pracy 1932, s. 93-104.

44 PAOB, z. 377, op. 1, t. 6, k. 44-44v. - wykaz paszportów zagranicznych (do Stanów Zjednoczonych) wydanych w drugiej połowie 1931 roku na terenie województwa poleskiego.

45 Statystyka... 1932, s. 93-104.

46 A. Reczyńska, Emigracja z Polski do Kanady w okresie międzywojennym, Wrocław 1986, s. 24-25, 207.

47 Rocznik statystyki... 1923, s. 25-27; ibidem (1925-26), s. 99-100; Statystyka... 1932, s. 93-104; ibidem (1933), s. 39-45; ibidem (1934), s. 38; ibidem (1935), s. 62; ibidem (1936), s. 53; ibidem (1937), s. 68; ibidem (1938), s. 25; ibidem (1939), s. 38; A. Reczyńska, op. cit., s. 31-34.

48 Rocznik statystyki... (1920-22), s. 337; ibidem (1923), s. 25-27; ibidem (1925-26), s. 99-100. 
polski akceptował działalność na swoim terenie legalnych agentów kanadyjskich towarzystw kolejowych. W następstwie tej polityki, w kolejnym 1926 roku z województwa poleskiego do Kanady wyjechało już 785 osób ${ }^{49}$.

Pod koniec lat dwudziestych XX wieku Kanada stała się ważnym kierunkiem emigracji z Polski ludności wyznania katolickiego i grekokatolickiego. Przyjęła też około jednej czwartej wychodźtwa prawosławnego z Polski, pochodzących przede wszystkim z województwa wołyńskiego i poleskiego. Większość emigrantów była rolnikami lub robotnikami przemysłowymi, znikomy był udział osób biernych zawodowo. Tak samo jak przed I wojną światową, w poszukiwaniu pracy i ziemi wyjeżdżali nieposiadający rodzin młodzi mężczyźni, w tym głowy rodzin, często pozostawiając w kraju żony i dzieci. Łącznie emigracja z województwa poleskiego do Kanady w latach 1926-1930 osiągnęła 6 tys. osób ${ }^{50}$.

W pierwszej połowie lat dwudziestych emigranci kierowali się głównie do prowincji Ontario i Manitoba, a od połowy lat dwudziestych do Wielkiego Kryzysu Gospodarczego (lata obowiązywania umowy kolejowej) - głównie do Manitoby. W latach kryzysowych część emigrantów w poszukiwaniu pracy, przeniosła się do prowincji wschodnich. W okresie kryzysu zostały odwołane pozwolenia na sprowadzenie imigrantów wydane kompaniom kolejowym. Ograniczenia imigracyjne nie dotyczyły jednak członków rodzin wcześniej przybyłych migrantów, w zwiazku z czym znacznie wzrosła liczba sprowadzanych z kraju kobiet i dzieci. W drugiej połowie lat trzydziestych struktura emigracji z województwa poleskiego do Kanady była nieco bardziej zrównoważona, ale wychodźstwo nie osiągnęło już nigdy poziomu z lat przedkryzysowych ${ }^{51}$.

Argentyna, dzięki rozwiniętemu rolnictwu i eksportowi wyrobów rolnych, stała się $\mathrm{w}$ pierwszej połowie $\mathrm{XX}$ wieku jednym $\mathrm{z}$ bogatszych państw, przyciągającym wychodźców z całego świata. Rząd argentyński wspierał imigrację i np. na przełomie XIX i XX wieku pokrywał koszty podróży imigrantów z portu do osady ${ }^{52}$.

Dla mieszkańców województwa poleskiego w okresie międzywojennym Argentyna stała się najważniejszym kierunkiem wychodźstwa, gdzie łącznie wyemigrowało ponad 14 tys. osób ${ }^{53}$.

49 Statystyka... (1932), s. 93-104; A. Brożek, op. cit., s. 138; E. Kołodziej, op. cit., s. 66; H. Janowska, Emigracja zarobkowa..., s. 136-137.

50 Rocznik statystyki... (1928), s. 69-76; ibidem (1929), s. 19-25; Statystyka... (1932), s. 93-104.

51 Maty Rocznik... (1939), s. 52-55; Statystyka... (1932), s. 93-104; ibidem (1933), s. 39-45; ibidem (1934), s. 38; ibidem (1935), s. 62; ibidem (1936), s. 53; ibidem (1937), s. 68; ibidem (1938), s. 25; ibidem (1939), s. 38; A. Reczyńska, op. cit., s. 62, 65-69; A. Brożek, op. cit., s. 138; H. Janowska, Emigracja z Polski..., s. 387.

52 A. Brożek, op. cit., s. 131; J. Mazurek, Kraj a emigracja: ruch ludowy wobec wychodźstwa chłopskiego do krajów Ameryki Łacińskiej (do 1939 roku), Warszawa 2006, s. 34.

53 Rocznik statystyki... (1923), s. 25-27; ibidem (1925-26), s. 99-100; Statystyka... (1932), s. 93-104; ibidem (1933), s. 39-45; ibidem (1934), s. 38; ibidem (1935), s. 62; ibidem (1936), s. 53; ibidem (1937), s. 68; ibidem (1938), s. 25; ibidem (1939), s. 38; J. Mazurek, op. cit., s. 34. 
Zahamowanie ruchów migracyjnych przyniosła I wojna światowa. Odbudowa masowego wychodźstwa odbyła się nie odrazu. W 1921 roku wyjechało do Argentyny z województwa poleskiego ok. 135 osób $^{54}$. W następnych latach znaczenie Argentyny jako kraju docelowego wychodźstwa wzrastało, a wśród emigrantów przeważała ludność żydowska. W 1925 roku do Argentyny wyjechał co czwarty wychodźca z Polesia (551 osób) ${ }^{55}$.

Od 1927 roku struktura narodowościowo-wyznaniowa emigracji do Argentyny zaczęła się zmieniać; notowano ciągły wzrost wychodźstwa ludności chrześcijańskiej, a w szczególności prawosławnej. Większość emigrantów była rolnikami lub robotnikami przemysłowymi; znikomy był udział osób biernych zawodowo. W strukturze emigracji do Argentyny liczba mężczyzn znacznie przewyższała liczbę kobiet, wśród wychodźców praktycznie nie było dzieci. W okresie maksymalnego natężenia emigracji (lata 1925-1930) z województwa poleskiego wyemigrowało tam ponad 10 tys. wychodźców ${ }^{56}$.

Na początku kryzysu, emigracja do Argentyny znacznie spadła, ponieważ w obliczu narastającego bezrobocia, kraj ten zaczął podwyższać opłaty wizowe w celach redukcji liczby imigrantów. Ożywienie migracyjne nastąpiło od 1936 roku i trwało do momentu wstrzymania wydania wiz w 1938 roku osobom kierującym się do północnej prowincji Misiones ${ }^{57}$.

Ograniczenia wizowe spowodowały poszerzenie nielegalnej migracji do Misiones z pobliskiego Paragwaju. Ucieczki osadników z Paragwaju do Argentyny przybrały charakter na tyle masowy, że sięgały do 30\% ogólnej liczby przyjeżdżających do Paragwaju emigrantów z Polski. Fakt ten negatywnie wpływał na stosunki polskie z władzami obu krajów ${ }^{58}$.

Po gorączce brazylijskiej z przełomu wieków, wychodźstwo do Brazylii uległo zahamowaniu po I wojnie światowej. Podstawową przyczyną było zaprzestanie dofinansowania kosztów przejazdu imigrantów przez rząd brazylijski. Wychodźcy z Polski pochodzili głównie z województw centralnych i południowo-wschodnich, większość emigrantów stanowili Żydzi ${ }^{59}$.

\footnotetext{
54 Rocznik statystyki... (1920-22), s. 337.

55 Rocznik statystyki... (1923), s. 25-27; ibidem (1925-26), s. 99-100.

56 Ibidem (1927), s. 95-99; ibidem (1928), s. 69-76; ibidem (1929), s. 19-25; ibidem (1930), s. 29-34; Statystyka... (1932), s. 93-104.

57 H. Janowska, Emigracja z Polski..., s. 386; A. Kicinger, op. cit., s. 13; J. Mazurek, op. cit., s. 38 .

58 PAOB, z. 2082, op. 1, t. 12, k. 42 - pismo wydziału pasażerskiego Syndykatu Emigracyjnego do wszystkich oddziałów i agentur Syndykatu z dnia 1 września 1938 roku w sprawie ścisłego dobierania osadników do Paragwaju; ibidem, k. 45 - zawiadomienie Syndykatu Emigracyjnego do wszystkich oddziałów i agentur Syndykatu z dnia 21 maja 1938 roku w sprawie Paragwaju; A. Zarychta, op. cit., s. 31; A. Kicinger, op. cit., s. 11.

59 Rocznik statystyki... (1920-22), s. 337; J. Mazurek, op. cit., s. 9, 61.
} 
Z województwa poleskiego do Brazylii w okresie międzywojennym wyjechało ok. 3 tys. osób. Była to emigracja osadnicza, na co wskazuje też wysoki odsetek osób biernych zawodowo ${ }^{60}$.

Pod koniec lat dwudziestych XX wieku w strukturze narodowościowo-wyznaniowej emigracji wzrósł udział chrześcijan (do ponad 70\%). Swój szczyt wychodźstwo z Polesia do Brazylii osiągnęło w 1929 roku, w którym wyjechało 806 osób. Wtedy dla ludności prawosławnej, która dominowała wśród emigrantów z Polesia, Brazylia stała się trzecim (po Argentynie i Kanadzie) ważnym kierunkiem wychodźstwa ${ }^{61}$.

Po spadku wychodźstwa w latach kryzysowych, emigracja z województwa poleskiego do Brazylii wzrosła na krótko w latach 1936-1937, osiągając łącznie 787 osób. Kres nasileniu wychodźstwa położyła nowa polityka władz brazylijskich, które dążyły do asymilacji mniejszości narodowych, ograniczając zarazem napływ nowych przybyszów przez wprowadzenie kwot imigracyjnych ${ }^{62}$.

\section{Zakończenie}

Leżące na peryferiach II RP województwo poleskie było specyficznym regionem z niskim potencjałem rolniczym, nierozwiniętym przemysłowo, słabo zaludnionym, a posiadającym jednocześnie zróżnicowaną strukturę narodowościową (Białorusini, Polacy, Poleszucy, Rosjanie, Ukraińcy, Żydzi) i wyznaniową (katolicy obrządków zachodniego i wschodniego, prawosławni, luteranie, wyznawcy judaizmu). Poziom życia ludności był tam jednym $\mathrm{z}$ najniższych $\mathrm{w}$ międzywojennej Polsce.

Emigracja $\mathrm{z}$ województwa poleskiego składała się z kilku nurtów, pokrywających się z wychodźstwem poszczególnych grup narodowościowo-wyznaniowych: Żydów, katolików-Polaków oraz prawosławnych: Białorusinów, Ukraińców i Poleszuków, choć ci ostatni nie zostali bezpośrednio odźwierciedleni w statystykach emigracyjnych.

$\mathrm{W}$ pierwszych latach rozpatrywanego okresu, emigracja z Polesia była w znacznym stopniu wychodźstwem żydowskim, głównie do USA. Po wprowadzeniu przez Stany Zjednoczone ograniczeń imigracyjnych w 1921 i 1924,

60 Rocznik statystyki... (1923), s. 25-27; ibidem (1925-26), s. 99-100; Statystyka... (1932), s. 93-104; ibidem (1933), s. 39-45; ibidem (1934), s. 38; ibidem (1935), s. 62; ibidem (1936), s. 53; ibidem (1937), s. 68; ibidem (1938), s. 25; ibidem (1939), s. 38.

${ }^{61}$ Statystyka... (1932), s. 93-104.

62 Maty Rocznik... (1939) s. 52-55; Statystyka... (1933), s. 39-45; ibidem (1934), s. 38; ibidem (1935), s. 62; ibidem (1936), s. 53; ibidem (1937), s. 68; ibidem (1938), s. 25; ibidem (1939), s. 38; A. Brożek, op. cit., s. 136-137; J. Mazurek, op. cit., s. 38, 61. 
fala wychodźstwa żydowskiego przekierowała się do Palestyny i Argentyny oraz w mniejszym stopniu - do innych krajów Ameryki Północnej i Południowej.

Po przewrocie majowym i objęciu rządów w kraju przez obóz sanacyjny, zaczęła wzrastać emigracja ludności prawosławnej. Województwo poleskie było jednym z najważniejszych w II RP zagłębi wychodźstwa prawosławnego. W okresie maksymalnego natężenia emigracji w latach 1927-1929 z Polesia wyjechało za ocean 7,7 tys. prawosławnych, co stanowiło blisko jedną trzecią wszystkich emigrantów prawosławnych z Polski. Więcej osób wyznania prawosławnego wyemigrowało $\mathrm{w}$ tym okresie tylko z Wołynia.

Województwo poleskie zamieszkiwane przez Białorusinów było najważniejszym źródłem emigracji zamorskiej tej ludności. Przykładowo, w 1926 roku z 527 wychodźców-Białorusinów z Polski, 414 osób pochodziło z Polesia ${ }^{63}$.

W literaturze poświęconej tematyce emigracyjnej wskazuje się, że działania polskiego rządu nigdy nie doprowadziły do przymusowego wychodźstwa mniejszości narodowych. Jednocześnie dostępne dane odnośnie Polesia i Wołynia skłaniają do wniosku, że dla ludności prawosławnej na tych ziemiach, tak samo jak dla ludności grekokatolickiej w województwach południowo-wschodnich, stworzono warunki maksymalnie ułatwiające wyjazd za ocean. Wniosek ten dotyczyć oczywiście będzie też ludności żydowskiej.

Wychodźstwo z terenów województwa poleskiego nielicznych Polaków przez cały okres międzywojenny kierowało się do USA i Kanady, a także - w ramach akcji kolonizacyjnej - do Argentyny i innych krajów Ameryki Łacińskiej.

Na podstawie dostępnych danych możemy stwierdzić, że emigracja z województwa poleskiego za ocean (z wyjątkiem Palestyny) w latach 1921-1938 wyniosła ponad 37 tys. osób. Głównymi kierunkami były Argentyna (38\% emigracji z Polesia), USA (24\%) i Kanada (21\%). W poszczególnych latach dość popularnymi krajami docelowymi emigracji były też Brazylia ( $8 \%$ emigracji z Polesia) i Paragwaj (4\%).

\section{Exodus overseas form the Polesie Voivodeship. An outline of issues}

In the article emigrational processes and main directions in the exodus from the Polesie Voivodeship to countries of North and South America in the interwar period have been presented. Internal and external conditions of the exodus processes, including emigrational policy of the Second Commonwealth, have been taken into account.

63 Rocznik statystyki... (1927), s. 95-99. 
The Polesie Voivodship, constituting a part of the eastern borderlands (Kresy Wschodnie), was a sparsely populated and economically undeveloped region, with a variety of nationalities and denominations. Emigration from the Polesie Voivodeship can be subdivided into a couple of groups, according to their nationality and denomination: Jews, Poles, Orthodox Belarusians, Ukrainians and Polishchucs.

The author of the article underlines the importance of the Polesie Voivodeship in the exodus of Orthodox population from the II Commonwealth.

Key words: Polesie Voivodeship, emigration, interwar period, Eastern Borderland, exodus

\section{Aneks}

\section{Załącznik 1. Podział administracyjny województwa poleskiego}

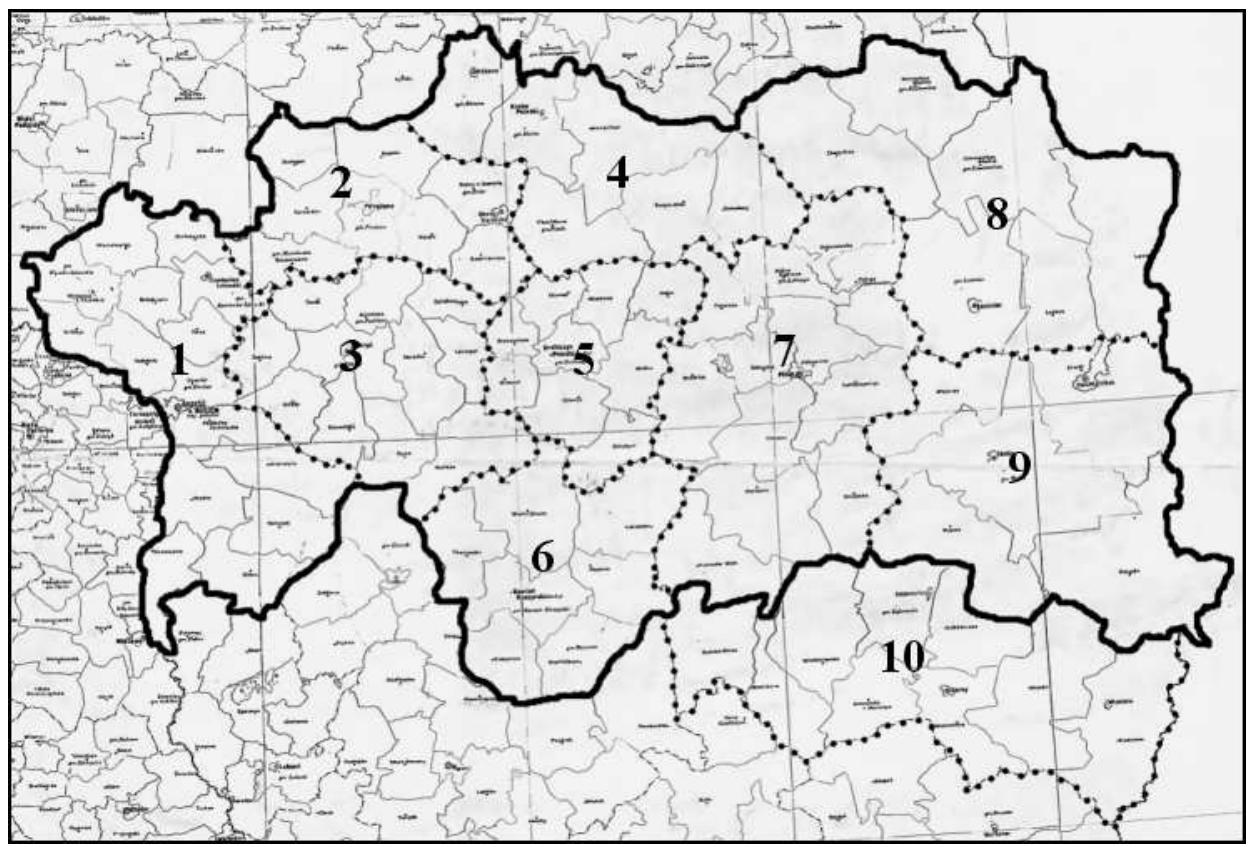

Legenda: 1 - powiat brzeski, 2 - powiat prużański, 3 - powiat kobryński, 4 - powiat iwacewicki (do 1935 roku - kosowski), 5 - powiat drohicki, 6 - powiat kaszyrski, 7 - powiat piński, 8 - powiat łuniniecki, 9 - powiat stoliński, 10 - powiat sarneński (od 1930 roku w województwie wołyńskim).

Źródło: opracowanie własne na podstawie: Mapa gmin Rzeczypospolitej Polskiej. Podział administracyjny według stanu z 1 kwietnia 1938 roku. 


\section{Bibliografia}

\section{Źródła}

Atlas statystyczny, Warszawa 1930.

Dekret o organizacji państwowych urzędów pośrednictwa pracy i opieki nad wychodźcami, Dz. U. R. P. Nr 11 (1919), poz. 127.

Drugi powszechny spis ludności. Mieszkania i gospodarstwa domowe. Ludność. Stosunki zawodowe. Województwo poleskie, Warszawa 1938.

Mały rocznik statystyczny (1938), s. 30, 33, 37; (1939), s. 52-55.

Państwowe Archiwum Obwodu Brzeskiego (PAOB), z. 377, op. 1, t. 6, k. 1, 6, 44-44v, 73-73v, 78-78v - teki okręgowego oddziału Syndykatu Emigracyjnego w Brześciu n/B. Listy ekspozytury Urzędu Emigracyjnego w Brześciu n/B, wojewody poleskiego, wykaz paszportów zagranicznych do USA.

PAOB, z. 2082, op. 1, t. 3, k. 10, 74-75; t. 5, k. 225, 227; t. 12, k. 42, 45; t. 78, k. 1-3 - teki oddziału Syndykatu Emigracyjnego w Pińsku. Dokumenty Ministerstwa Pracy i Opieki Społecznej, centrali Syndykatu Emigracyjnego w Warszawie, agentury Syndykatu Emigracyjnego w Pińsku.

Problem emigracyjny $i$ surowcowy w Polsce, Warszawa 1937.

Rocznik statystyki Rzeczypospolitej Polskiej (1920-22), s. 335, 337; (1923), s. 9, 14, 25-27, 29; (1925-26), s. 99-100; (1927), s. 95-99; (1928), s. 69-76; (1929), s. 19-25; (1930), s. 29-34.

Rozporządzenie Prezydenta Rzeczypospolitej z dnia 29 listopada 1930 r., Dz.U.R.P. Nr 82 (1930), poz. 649.

Rozporządzenie Rady Ministrów w przedmiocie utworzenia Urzędu Emigracyjnego przy

Ministerstwie Pracy i Opieki Społecznej, Dz.U.R.P. Nr 39 (1920), poz. 232.

Rozporządzenie Rady Ministrów z dnia 9 czerwca 1921 r., Dz.U.R.P. Nr 64 (1921), poz. 403.

Rozporządzenie Rady Ministrów z dnia 6 grudnia 1922 r., Dz.U.R.P. Nr 116 (1922), poz. 1051.

Rozporządzenie Rady Ministrów z dnia 4 maja 1926 r., Dz.U.R.P. Nr 45 (1926), poz. 277.

Rozporządzenie Rady Ministrów z dnia 14 lipca 1926 r., Dz.U.R.P. Nr 72 (1926), poz. 799.

Rozporządzenie Prezydenta Rzeczypospolitej z dnia 11 października 1927 r., Dz.U.R.P. Nr 89 (1927), poz. 799.

Rozporządzenie Prezydenta Rzeczypospolitej z dnia 21 czerwca 1932 r., Dz.U.R.P. Nr 52 (1932), poz. 492.

Skorowidz miejscowości Rzeczypospolitej Polskiej, t. VIII, Warszawa 1924.

Statystyka pracy (1932), s. 93-104; (1933), s. 39-45; (1934), s. 38; (1935), s. 62; (1936), s. 53; (1937), s. 68; (1938), s. 25; (1939), s. 38. 


\section{Literatura}

Ameryka Łacińska w relacjach Polaków, (red.) M. Kula, Warszawa 1984.

Brożek A., Polityka imigracyjna w państwach docelowych emigracji polskiej (1850 -1939), [w:] Emigracja z ziem polskich $w$ czasach nowożytnych $i$ najnowszych (XVIII-XX w.), (red.) A. Pilch, Warszawa 1984.

Cichoracki P., Polesie nieidyliczne. Zaburzenia porządku publicznego $w$ województwie poleskim w latach trzydziestych XX w., Lomianki 2007.

Gawryszewski A., Ludność Polski w XX wieku, Warszawa 2005.

Janowska H., Emigracja zarobkowa z Polski 1918-1939, Warszawa 1981.

Janowska H., Emigracja z Polski w latach 1918-1939, [w:] Emigracja z ziem polskich w czasach nowożytnych i najnowszych (XVIII-XX w.), (red.) A. Pilch, Warszawa 1984.

Kępińska E., Migracje sezonowe z Polski do Niemiec. Mechanizmy rekrutacji, rola rodziny i zróżnicowanie według ptci, Warszawa 2008.

Kicinger A., Polityka emigracyjna II Rzeczpospolitej, Warszawa 2005.

Kirwiel E., Kresy Pótnocno-Wschodnie Rzeczypospolitej Polskiej w latach 1918-1939. Oblicze polityczne, Lublin 2011.

Kołodziej E., Wychodźstwo zarobkowe z Polski 1918-1939, Warszawa 1982.

Kujawa A., Polacy w Kanadzie, Warszawa 2008.

Majecki H., Problem samookreślenia narodowego Poleszuków w Polsce okresu międzywojennego, [w:] Загароддзе-3, Мінск 2001.

Mazurek J., Kraj a emigracja. Ruch ludowy wobec wychodźstwa chłopskiego do krajów Ameryki Łacińskiej (do 1939 roku), Warszawa 2006.

Polesie w polityce rządów II Rzeczypospolitej, Białystok-Kraków 2009.

Radomska M., Syndykat Emigracyjny S.A. - historia i organizacja, „Biuletyn Migracyjny" 2011, nr 28.

Reczyńska A., Emigracja z Polski do Kanady w okresie międzywojennym, Wrocław 1986.

Słownik geograficzny Królestwa Polskiego i innych krajów słowiańskich, t. VIII, Warszawa 1887.

Stasik F., Polska emigracja zarobkowa w Stanach Zjednoczonych Ameryki 1865-1914, Warszawa 1985.

Śleszyński W., Województwo poleskie, Kraków 2014.

Wysocki A., Zarys problemu świadomości narodowej rdzennych mieszkańców województwa poleskiego w świetle dokumentów Centralnego Archiwum Wojskowego, ,Biuletyn Wojskowej Służby Archiwalnej” 2005, nr 27.

Zarychta A., Emigracja polska 1918-1933 i jej znaczenie dla państwa, Warszawa 1933.

Государственный архив Брестской области. Путеводитель по фондам 19191939, Брест 2010. 
Мощук А.В., Политическая деятельность Бунда на территории Западной Беларуси в 1921-1939 г2., „Веснік Брэсцкага універсітэта” 2007, nr 2.

Терешкович П., Этническая история Беларуси XIX - начала XX в. в контексте Центрально-восточной Европы, Минск 2004. 